\title{
HEGEL'S RECEPTION IN FRANCE
}

It may well be that the future of the world, and thus the sense of the present and the significance of the past, will depend in the last analysis on contemporary interpretations of Hegel's works. (Alexandre Kojève)

This bibliographic guide was developed by A. Bohm. It was completed by V. Y. Mudimbe in conjunction with a graduate seminar on "The German Crisis of French Thought" he held in the Graduate Program in Literature, Duke University (Spring, 1992). The title of the seminar was inspired by Claude Digeon's book, La Crise allemande de la pensee française, which analyzes similar problems in the literary field until the 1920's. The purpose of this guide was not to achieve bibliographical exhaustiveness, but rather to give an overview of the sequence and shape of the French Hegel reception. The chronological listing in Part I integrates the major translations of Hegel texts into French in sequence with decisive readings by key French philosophers. Thereby some of the patterns of reception that are otherwise obscured by alphabetical listings and by the separation of primary from secondary texts come to light.

An informed guide can often point out features that might otherwise go unnoticed in a bewilderingly full (or apparently monotonous) landscape. The organization of the bibliography, the historical presentation of the reception and the annotations have been made by $\mathrm{V}$. Y. Mudimbe and then edited by A. Bohm. The aim of the guide is to highlight figures and texts as important events in this area of the complex dialogue between French and German philosophy. Somewhat more than a simple bibliography, then, this guide may be useful as notes towards a history yet-to-be-written. Part II provides an alphabetical list of secondary surveys and studies dealing with the contemporary French reception of German philosophy, with the overall reception of Hegel in France and with specific moments.

The term "reception" is used here with an awareness of the extensive discussion by literary historians and critics of the inadequacies of competing concepts such as that of "influence." Reception is the active 
appropriation of authors, ideas, themes and so forth by one culturalintellectual system for the purposes of another one. The creditor system has only indirect control in this process, primarily in producing and making texts available. Some of the impulses for Hegel reception can be attributed to the German interest in a Hegel who can be opposed to the image of the official or Prussianized establishment philosopher, and this seems to have been reflected in the French interest in the Jena period as well as in the Hegel transmitted by Marx. ${ }^{1}$

From the French side, the translation of Hegel texts is an important dimension of the reception for several reasons. First, translations, especially when they come in clusters (as in the early 1970s) or have some particular institutional support (as in the case of Hyppolite), attract attention to figures and problems. On the most elementary level, the mere fact of making Hegel more widely available increased his visibility. Second, every translation is implicitly an interpretation, so that the shifts in the French discourse on Hegel could be traced here. Third, translations are often accompanied by commentaries--those of Kojeve and Hyppolite come to mind immediately. The importance of such commentaries needs to be emphasized for an English-speaking philosophical audience, where the commentary as a genre and mode of philosophizing has been de-emphasized. ${ }^{2}$ Within the tradition of commentary, book reviews also deserve mention, especially those appearing in leading intellectual journals. These reviews are frequently succinct declarations of the concerns of the discourse at a given moment.

Of course, the existence of translations of Hegel does not imply that the French had no access to primary and secondary texts in German. Quite the contrary was the case, as a systematic study of citations would show. Ideally, one would complement the history of the French reception

${ }^{1}$ For one analysis of such factors in Hegel, see Ricardo Pozzo, "Le edizioni dei Corteggi di Hegel e la storia della critica," Revista di storia della filosofia NS 42.2 (1987): 237-271.

2 See on this point Barry Smith, "Textual Deference," American Philosophical Quarterly 28.1 (1991): 1-12. 
with an awareness of German philosophy as a whole. Hegel reception ultimately cannot be separated from the reception of the entire German philosophical tradition. Three instances might be cited. The reception of Husserlian phenomenology quickly entailed an awareness of, if not an explicit return to, Hegel. Any serious engagement with the thought of Marx could not ignore Hegel. And Heidegger's relationship to Hegel, even where it does not come under the explicit category of "Hegel reception," was of a piece with it.

From the bibliographic perspective, claims for ruptures in the pattern of reception seem rather overstated. Mark Poster observed that "the sudden prominence of Hegel among the French intellectuals after World War II signified a breach with traditions of thought," and went on to assert: "Only 'offbeat' intellectuals like Andre Breton's surrealists and a circle of young Marxists in the 1920's paid tribute to the German dialectician. ${ }^{33}$ In fact this is contradicted by the history that emerges bibliographically. For example, Jean Wahl, Alexandre Koyre and Jean Hyppolite provided a bridge from scholars such as Victor Delbos and Victor Basch to the existentialists. The Marxist dimension should not be stressed to the exclusion of the simultaneous reception of other aspects of Hegel's writings, including those affecting theology, aesthetics, and the philosophy of science. Nor should the role of Louvain as another important philosophical center beside Paris be ignored.

One final caveat might be registered about the illusory force of all bibliographies, especially brief ones. They tend to suggest orderliness and purposiveness where in fact there were (and are) wrong turns, loose ends, incomplete projects, redundancies, and coincidences. Reception is an abstract formula for the process of many readers reading--and misreading--in productive and curious ways.

\section{BASIC SOURCES}

In his study "Hegel in France," G. Canguilhem, writing in the late 1940 s, notes that the most important and original phenomenon in the French case is the discovery of Hegel and his introduction in France one

${ }^{3}$ Mark Poster, Existential Marxism in Postwar France: From Sartre to Althusser (Princeton: Princeton UP, 1975), p. 3-4. 
century after his death. ${ }^{4}$ Hegel (1770-1831) was not an unknown thinker for Cousin, Renan and Taine in the XIXth century. At the end of that century, Lucien Herr, for instance, was perfectly acquainted with Hegel's philosophy. Yet he chose not to divulge his knowledge of the German philosopher's contribution. Seen as a symbolic embodiment of panGermanism, Hegel, as well as other German thinkers, are victims of two conflicting nationalisms--the German and the French--and this tension was maximized by the Franco-Prussian War in 1870. According to Canguilhem, it is thus only in the late 1920 s and in the 1930s that one can observe a progressive introduction and reception of Hegel's philosophy in France. Some of the milestones of this transformation would have been: Jean Wahl's Le Malheur de la Conscience dans la Philosophie de Hegel (1929); Alexandre Kojeve's teachings on Hegel (1933-1939) at the Ecole des Hautes Etudes; and, indeed, the achievement represented by Jean Hyppolite's translation of Phenomenologyof Spirit (1939 and 1941).

One could thus distinguish two major periods in the French reception of Hegel: one before 1930; the other, after.

\section{Before 1930}

The bulk of Hegel's work was translated into French by Augusto Véra who, in 1861, published a general introduction to Hegelianism--Le Hégélianisme et la philosophie (Paris: Ladrange). Here, presented chronologically, are Hegel's first French translations:

1.1.1. Hegel, G.W.F. La philosophie de l'esprit. Transl. Augusto Véra. Paris: Germer-Bailliere, 1867 (Vol. 1); 1869 (Vol. 2). Rpt. Brussels: Culture et civilisation, 1969.

1.1.2. Hegel, G.W.F. La philosophie de la nature. Transl. Augusto Véra. Paris: Ladrange, 1863 (Vol. 1); 1864 (Vol. 2). Rpt. Brussels: Culture et civilisation, 1969.

1.1.3. Hegel, G.W.F. Logique. Transl. Augusto Véra. 1859. Second ed. Paris: Germer, 1874. Rpt. Brussels: Culture et civilisation, 1969.

4 Georges Canguilhem, "Hegel en France," Revue d'Histoire et de Philosophie Religieuses, $28-29$ (1948-49): 282-297. 
1.1.4. Hegel, G.W.F. Esthétique. Vol. 1. Trans. Ch. Benard. Paris: Germer-Baillière, 1875.

1.1.5. Hegel, G.W.F. La philosophie de la religion. Transl. Augusto Véra. Paris: Germer-Baillière, 1876 (Vol. 1), 1878 (Vol. 2). Rpt. Brussels: Culture et civilisation, 1969.

With respect to the translation of Hegel, one should also mention the contributions of Benard, Slowan and Wallon, who had published in 1854.

According to A. Koyré, Véra was "un disciple plus enthousiaste que compétent" (Etudes d'Histoire de la Pensée Philosophique, Paris: Colin, 1961: 206), and his translation was poor.

Georges Canguilhem is also very harsh in his evaluation of Véra's work: "L'ancienne traduction de Véra ne jouissait que d'un crédit limité. C'etait un pis-aller" (1948-9: 284). In 1969 these versions were reprinted and one could consult a more systematic analysis of Véra's work by consulting André Joz' article: "Véra, traducteur et interprète de Hegel" (Annali della Scuola Normale Superiore, Pisa, 1986: 1265-77). Nonetheless, Vera's translation is the most commonly consulted, even by specialists. Major critical contributions at the end of the XIXth century and at the beginning of the XXth include:

1.1.6. Lévy-Bruhl, Lucien. La théorie de l'Etat dans Hegel. Paris: A. Picard, 1889.

A fascinating analysis on the notion of State which one could usefully read in conjunction with Jean Hyppolite's study on the significance of the French Revolution in Hegel's Phenomenology.

1.1.7. Jaurès, Jean-Lêon. De primis socialismi germanici lineamentis apud Lutherum, Kant, Fichte et Hegel. Paris, 1892.

An overview of the main socialist themes in the writings of Luther, Kant, Fichte and Hegel. A doctoral dissert-ation written in Latin, Jaurès' text is highly scholastic.

1.1.8. Noêl, Georges. La Logique de Hegel. Paris: Vrin, 1897, 1933. 
The 1933 version is a simple re-publication of the 1897 edition.

1.1.9. Roques, Paul. Hegel, sa vie et ses oeuvres. Paris: Alcan, 1912.

An excellent (and the first) biography of Hegel in which a connection is established between the life and work of the German philosopher.

1.1.10. Delbos, Victor. "Le premier principe comme pensée infinie (Hegel)." Revue de métaphysique et de morale 28 (1921): 37-47.

1.1.11. Delbos, Victor. "Les facteurs kantiens dans la philosophie allemande à la fin du XVIII siècle." Revue de métaphssique et de morale (1919): 569-; (1920): 1-; (1921): 27-; (1922): 157 Rpt. in Victor Delbos, De Kant aux post-kantiens. Paris: Aubier, 1939.

1.1.12. Delbos, Victor. "La méthode de démonstration chez Hegel." Revue de métaphysique et de morale 32 (1925): 271-281.

Victor Delbos, a specialist of Kant (La philosophie pratique de Kant, Paris, 1902) had already focused on Hegel in one chapter of his $L e$ probleme moral dans Spinoza et dans I'histoire du spinosisme (1902), and had compared and opposed Hegel and Schelling in his Latin doctoral dissertation: De posteriori Schellingii philosophia quatenus hegelianae adversatur (1902). From 1922 to 1929, Delbos taught a course on Hegel at the Sorbonne. Lucien Levy-Bruhl, best remembered today as the inventor of concepts such as "pre-logism" and "mystical mentality," was then a careful student of German philosophy. Indeed, he had published on German philosophy ( $L$ 'Allemagne après Leibniz, 1890 ) as well as on Jacobi (La Philosophie de Jacobi, 1894). And to Jaurès' thesis, one should add Charles Andleres remarkable book on the origins of State socialism in which one finds startling statements such as: "The Hegelian system is an effort [. . . ] to found liberty through reason; or, the Hegelian system could stand as it is even if the world did not exist."

\subsubsection{Charles Andler, Les origines du socialisme d'Etat en Allemagne, Paris, 1897.}

Alexandre Koyre invokes the influence of Boutroux and his teachings in order to account for the general interest in Hegel. Boutroux, 
himself the author of important publications in the field of German philosophy-e.g. Essais d'histoire de la Philosophie, 6th edition 1929, and La Philosophie allemande au XVIF siecle, Paris, 1928--was, along with $\mathrm{R}$. Berthelot and V. Delbos, one of the participants in an historical session of the Societe française de Philosophie that discussed Hegel's philosophy on January 31, 1907. R. Berthelot's report presents Hegel's philosophy as a "dynamic idealism" which is not "an absolute determinism, nor an integral optimism, nor a panlogism" and thus against what he terms three French "traditional conceptions", that, in misreadings and misinterpretations, reduce Hegelianism to, or confuse it with "determinism," "integral optimism" and "panlogism," Berthelot and Delbos then summarize the state of Hegelian studies. In brief, the general climate in most of the studies is one of hostility toward Hegel's philosophy. Alexandre Koyre (1961: 207) suggested a series of reasons: Hegel's antimathematism could not be understood; his will to service a philosophy of nature in order to construct a new science seemed preposterous; the concept of a philosophy of history was not acceptable in an intellectual atmosphere dominated by Fustel de Coulanges' historical theories; and, finally, the way the "Protestant" Hegel faced religious issues could not easily be accepted in a profoundly Catholic France. This resistance to Hegel can be exemplified in the following quotation from E. Caro's book: "His philosophy emerged from the nothingness of being, went through the nothingness of becoming and ended in the nothingness of death." Two books written in this spirit were:

1.1.14. Caro, E., L'ideé de Dieu et ses nouveaux critiques. Paris, 1864.

\subsubsection{5. de Careil, Foucher, Hegel et Schopenhauer. Paris, 1862.}

The reception of Hegel is, for reasons analyzed by Koyre, basically negative or, as demonstrated by Berthelot, naive, confused and often erroneous. In his report on the state of Hegelian studies during this period Koyre (1961: 206) retained a number of publications which attest to the complexity of a reception:

Barchou de Penhoen, Histoire de la philosophie allemande, 2 vol., Paris, 1836; the excellent Histoire de la philosophie allemande (4 vol., Paris, 1849) of J. Willm who had already published in 1836 a study on Hegel: Essai sur la philosophie de Hegel, Strasbourg. Let us also note: A. Ott, Hegel et la philosophie allemande ou expose et examen critique des principaux systèmes de la philosophie allemande depuis Kant et specialement de celui de Hegel, Paris, 1844; - L 
Prevost, Hegel, exposition de sa doctrine, Paris, 1844; - the article by Hegel in the Dictionnaire des sciences philosophiques, Paris, 18441852; A Vera, Introduction a la philosophic de Hegel, Strasbourg, 1855; - articles by E. Saisset in the Revue des Deux Mondes (Feb 1846; March 1856; December 1860); - of E. Scherer (Ibid., Feb. 1861); - P. Janet, Études sur la dialectique dans Platon et dans Hegel, Paris, 1861; - A. Weber, Introduction historique a la philosophie hegelienne, Strasbourg, 1866; - Foucher de Careil, Hegel et Schopenhauer, Paris, 1862.

In sum, the reception of Hegel was certainly negative but complex, partially because Hegel did not face the "tree" represented by Cartesianism and its scientific roots. This is a major point emphasized by L. Brunschvicq (Le progrès de la conscience dans la philosophie occidentale, Paris, 1927, II: 396). One may also add the problem of Hegel's vocabulary. Koyre's article, "Note sur la langue et la terminologie Hégeliennes" (Revue Philosophique, 1931; and also in 1961: 175-204) includes this quotation from L. Herr about Hegel: "His terminology is his own [. . .] and does not probably contain a sole technical term that might have an equivalent in this abstract language of French philosophy" (Koyre, 1961: 175). Nonetheless, as already indicated by the books mentioned in the preceding pages, Hegel is, since the mid-XIXth century, quite present in the French philosophical landscape. Leon Brunschvicq put it nicely: "It is true not only for XIXth-century Germany, but for the whole of Europe that philosophy developed under the sign of Hegel" (1927: 395).

Around 1930, Hegel's French presence is an obvious fact. In his 1922 treatise on L'explication dans les sciences, Emile Meyerson celebrates Hegel and his Naturphilosophie. In 1928, D. Rosca publishes a translation of Hegel's Life of Jesus (Paris: J. Gamber). The same year Rosca defends a doctoral thesis on the influence of Hegel on Taine (L'influence de Hegel sur Taine, Paris, 1928). In 1928 and 1929, Charles Andler focuses on Hegel in two of his courses at the College de France. One could even say that Hegel's problematics are by then already part of the French philosophical horizon. Encouraged by Lucien Herr, Alain taught his first course on Hegel in 1923 and published a major piece on him in his Idees: Platon, Descartes, Hegel (1932). On the other hand, previous major studies by Léon Brunschvicq, Victor Basch, Emile Brehier and Jean Wahl devoted a considerable amount of space to the German philosopher:

1.1.16. Brunschvicq, Léon. Le progrès de la conscience dans la philosophie occidentale. Paris: Alcan, 1927. Vol. 1, Part 2: 382-401. 
1.1.17. Basch, Victor. La doctrine politique des philosophes classiques de l'Allemagne: Leibnitz, Kant, Fichte, Hegel. Paris, 1927.

It should be interesting to compare this study on German political ideas to the more restricted one on socialism by Jean Jaures (see 1.1.7). Basch's objective is to present a faithful image of Hegel's thought, and the book thus assumes polemical stances.

1.1.18. Brehier, Emile, Histoire de la philosophie allemande, Paris, 1922.

1.1.19. Wahl, Jean. Le malheur de la conscience dans la philosophie de Hegel. Paris: Rieder, 1929. Rpt. Paris: Presses Universitaires de France, 1951.

An examination of young Hegel's analyses of religious issues.

\section{After 1930}

After 1930, one finds two remarkable trends: on the one hand, the solidification and stabilization of Hegelian studies; on the other, the steady rearticulation of Hegel's French translations. Let us begin by presenting the latter:

1.2.0. Hegel, G.W.F. Leçons sur la philosophie de l'histoire. Vols. 1 and 2. Trans. J. Gibelin. Paris: J. Vrin, 1937. Rpt. Paris, 1946; 3rd ed. 1967.

1.2.1. Hegel, G.W.F. Morceaux choisis de Hegel. Ed. and transl. Henri Lefebvre and Norbert Gutermann. Paris: Gallimard, 1938. Rpt. Paris: Gallimard, 1969.

1.2.2. Hegel, G.W.F. "Autonomie et dependence de la conscience de soi." Transl. with commentary by Alexandre Kojève. Mesures 5.1 (15 January 1939): 109-139.

1.2.3. Hegel, G.W.F. Principes de la philosophie du droit. Transl. André Kaan. Preface by Jean Hyppolite. Paris: Gallimard, 1940. Preface also in Jean Hyppolite, Figures de la pensé philosophique, écrits de Jean Hyppolite (1931-1968). Paris: Presses Universitaires de France, 1971. 1: 73-91. 
1.2.4. Hegel, G.W.F. Phenoménologie de l'esprit. Vol. 2. Transl. Jean Hyppolite. Paris: Aubier, 1941.

1.2.5. Hegel, G.W.F. Esthétique. 4 vols. Transl. S. Jankélévitch. Paris: Aubier, 1944.

1.2.6. Hegel, G.W.F. Leçons sur la philosophie de l'histoire. Transl. J. B. Gibelin. Paris: J. Vrin, 1946.

1.2.7. Hegel, G.W.F. Les preuves de l'existence de Dieu. Transl. H. Niel. Paris: Aubier, 1947.

1.2.8. Hegel, G.W.F. Science de la logique. 2 vols. Transl. S. Jankélévitch. Paris: Aubier, 1947.

1.2.9. Hegel, G.W.F. L'esprit du christianisme et son destin. Transl. Jacques Martin. Intro. J. Hyppolite. Paris: Vrin, 1948.

1.2.10. Hegel, G.W.F. [Text about Hamann from the Jahrbücher für wissenschafliche Kritik, 1828]. Transl. in Pierre Klossowski, Les meditations bibliques de Hamann. Paris: Editions de Minuit, 1948. 65-117.

1.2.11. Hegel, G.W.F. Science de la logique. Transl. S. Jankélevitch. 2 vols. Paris: Aubier, 1949.

1.2.12. Hegel, G.W.F. Sa vie, son oeuvre by Andre Cresson and René Serreau, Translation of Hegel's texts. and notes by René Serreau, Paris, 1949.

1.2.13. Hegel, G.W.F. Précis de l'encyclopédie des sciences philosophiques. Translation J. Gibelin. Paris: J. Vrin, 1952.

1.2.14. Hegel, G.W.F. Premières publications: Différence des systèmes philosophiques de Fichte et de Schelling; Foi et savoir. Transl. Marcel Méry. Paris: J. Vrin, 1952.

1.2.15. Hegel, G.W.F. Précis de l'Encyclopédie des sciences philosophiques. Transl. J. Gibelin. Paris: Vrin, 1952.

1.2.16. Hegel, G.W.F. Esthétique. Textes choisis par Claude Khodos, 
Paris, 1954.

1.2.17. Hegel, G.W.F. Leçons sur l'Histoire de la philosophie. Transl. J. Gibelin, Paris, 1954.

1.2.18. Hegel, G.W.F. Leçons sur la philosophie de la Religion; 3e partie. La religion absolue. Transl. J. Gibelin. Paris: 1954.

1.2.19. Hegel, G.W.F. Propédeutique philosophique. Transl. Maurice de Gandillac. Geneva: Editions Gonthier, 1963.

1.2.20. Hegel, G.W.F. Esthétique. Transl. S. Jankélevitch. 8 vols. in 10. Paris: Aubier-Montaigne, 1964-1965.

1.2.21. Hegel, G.W.F. La première philosophie de l'esprit (Iéna, 18031804). Tr. Guy Planty-Bonjour. Paris: P. U. F. de France, 1969.

1.2.22. Hegel, G.W.F. Encyclopédie des sciences philosophiques. Transl. Bernard Bourgeois. Paris: J. Vrin, 1970.

1.2.23. Hegel, G.W.F. La théorie de la mesure. Transl. André Doz. Paris: Presses Universitaires de France, 1970.

1.2.24. Hegel, G.W.F. La science de la logique. Transl. Bernard Bourgeois. Paris: Vrin, 1970.

1.2.25. Hegel, G.W.F. Science de la logique. Vol. 1, book 1: L'etre (1812 edition). Transl. and ed. Pierre-Jean Labarrière and Gwendoline Jarczyk. Paris: Aubier-Montaigne, 1972.

1.2.26. Hegel, G.W.F. Science de la logique. Vol. 1, Book 1: L'être (1812 edition). Transl. and ed. Pierre-Jean Labarrière and Gwendoline Jarczyk. Paris: Aubier-Montaigne, 1972.

1.2.27. Hegel, G.W.F. Le droit naturel. Transl. Andre Kaan. Paris: Gallimard, 1972.

1.2.28. Hegel, G.W.F. Des manières de traiter scientifiquement du droit naturel; de sa place dans la philosophie pratique et de son rapport aux sciences positives du droit. Transl. Bernard Bourgeois. Paris: Vrin, 1972. 
1.2.28. Hegel, G.W.F. La relation du scepticisme avec la philosophie, suivi de L'essence de la critique philosophique. Transl. B. Fauquet. Preface by J.-P. Dumont. Paris: Vrin, 1972.

1.2.29. Hegel, G.W.F. Principes de la philosophie du droit. Trans. R. Derathé. Paris: Vrin, 1975.

1.2.30. Hegel, G.W.F. La societé civile bourgeoise. Transl. Jean-Pierre Lefebvre. Paris: F. Maspero, 1975.

1.2.31. Hegel, G.W.F. Science de la logique. Vol 1, Book 2: La Doctrine de l'essence. Transl. and ed. Pierre-Jean Labarriere and Gwendoline Jarczyk. Paris: Aubier-Montaigne, 1976.

1.2.32. Hegel, G.W.F. Système de la vie éthique. Transl. Jacques Taminiaux. Paris: Payot, 1976.

Translations enabled a re-articulation of Hegel's presence in France. Before the 1930s Hegel's name and problematics were affirmed. Now, they were now established in the form of the work itself without mediation, in precise renderings of the German originals. In terms of chronology, Gibelin may be the first in this process (with his 1937 translation), but it is Jean Hyppolite who, with his masterful translation Phénoménologie de L'Esprit $(1939,1941)$, marks and re-orders the new Hegelian presence and designates new standards (in both translation and interpretation). Hyppolite's work imposed a new horizon for "indigenising" and questioning Hegel on his own terms. His French version of Hegel's Phenomenology is exemplary, indeed, arguing that it was "an event that transformed the situation of Hegelian studies in France," G. Canguilhem observed that:

One must admire in this work of translation not only the intrinsic faithfulness value, fruit of a really enormous work, but also the probity of the author who, wishing to elucidate Hegel's thought, began firstly by presenting it to all potential readers who could understand its expression and then evaluate it in a pertinent manner as well as so that they could know the interpretation proposed of it. The case is sufficiently rare, and it should be commented. Very often, philosophical originality consists today in using works which have remained esoteric without mentioning the sources. (1948-49: 285)

A major moment was marked by the publication of a special issue of the Revue de Metaphysique et de Morale in 1931. It coincided 
with the centenary of Hegel's death. The issue includes contributions by:

1.2.33. Von Astier, E., "Les aspects principaux de la philosophie allemande contemporaine," 38: 259-275.

It synthesizes the main trends in German philosophy. Beginning with the "failure"(!) of Hegelianism in mid-XIXth century, von Astier analyzes Kant's theory of knowledge, Husserl's Seinsphilosophie, Scheler's and Heidegger's philosophical anthropology, and the Wiener Kreis group, focusing on Wittgenstein.

1.2.34. Hartmann, Nicolaï, "Un cercle vicieux dans la critique de la philosophie hégélienne," 38: 277-316.

The article is on how to elaborate a pertinent critique of Hegel's philosophy.

1.2.35. Andler, Charles, "Le fondement du savoir dans la Phénoménologie de L'Esprit de Hegel," 38: 317-340.

In this patient analysis, Andler struggles with the concept of will to truth in Phenomenologyand demarcates in Hegel's project six types of reasoning corresponding to each other two by two. The conclusion is that, in Hegel true knowledge is one that accounts for Life, and Life supports this very knowledge. The truth of Life itself is to be proved by the satisfactions that it can give to the demands of Reason.

1.2.36. Basch, Victor, "Des origines et des fondements de l'Esthétique de Hegel," 38: 341-366.

How is it possible to understand Hegel's aesthetics as a closure of those of Plato and Plotinus, Schelling, Schiller and Kant?

1.2.37. Berthelot, René, "Goethe et Hegel," 38: 367-419.

Presentation of subtle analogies and contrasts between Goethe and Hegel, which involve a careful delineation of the intellectual genealogies of both thinkers and their connections with the thoughts of Fichte, Schiller, Schelling and Herder. 
1.2.38. Guéroult, Martial, "Le jugement de Hegel sur l'antithétique de la raison pure," 38: 413-439.

An analysis both of the determining influences that made the Hegelian system possible, and of how Hegel transformed logical affinities between concepts into an historical genesis. Seeking what announced Hegel, Gueroult examines Fichte, Jacobi, Kant, Reinhold, Schelling.

1.2.39. Vermeil, Edmond, "La pensée politique de Hegel," 38: 441-510.

Hegel is perceived here as "one of the most authentic representatives of his people, the German-type" who, disappointed by political reality, decides to invent an "ideal State" that does not exist. Accordingly, there is "a tragedy of Hegelian politics as there is a tragedy of German politics. In actuality, both tragedies are one and, thus, Hegel's political thought takes on a quasisymbolic aspect" (Vermeil, 38: 413).

The 1931 volume is a benchmark. Hegel's philosophy has been received and integrated in the tradition despite the fact that, as all things German, Hegel still arouses suspicion. Vermeil's analysis (1.2.39) exemplifies this. One could consult an elaborate study of this phenomenon.

1.2.40. Wahl, Jean. " La lutte contre le hégelianisme." in Jean Wahl, Etudes kierkegaardiennes. Paris: Aubier, 1938. 86-171.

Of this period, we should also mention an article by Victor Basch on Hegel's political philosophy, an excellent complement to that of Vermeil. (1.2.39)

1.2.41. Basch, Victor. "De la philosophie politique de Hegel. A propos d'un livre récent." Revue philosophiquede la France 56 (1931): 381-408.

The most noticeable contributions are signed by Alexandre Koyré and Jean Hyppolite.

1.2.42. Koyré, Alexandre. "Rapport sur l'état des études hégéliennes en France." Verhandlungen des Ersten Hegel-Congresses, vom 22. 
bis 25. April 1930 im Haag. Ed. B. Wigersma. Tübingen: J.C.B. Mohr/Haarlem: N/V H.D. Tjeenk Willink \& Zn, 1931. 80-105. Also in Revue d'histoire de la philosophie 5.2 (April-June 1931): 147-171. Rpt. with an update in Alexandre Koyré, Etudes d'histoire de la pensee philosophique. Paris: Armand Colin, 1961. 205-230.

The first systematic presentation of Hegelian studies in France. In 1961, the study will be included as a chapter in Etudes d'Histoire de la pensec philosophique (Paris: Colin).

1.2.43. Koyré, Alexandre. "Note sur la langue et la terminologie hégeliennes." Revue philosophique(1931). Also reprinted in the Etudes d'histoire de la pensée philosophique. Paris: Armand Colin, 1961, 175-204.

The best introduction to the complexity of Hegel's philosophical language.

1.2.44. Koyré, Alexandre. "Hegel à Iéna." Revue d'histoire et de philosophie religieuse (1934). Rpt. in his Etudes d'histoire de la pensée philosophique (Paris: Armand Colin, 1961): 135-173.

Presentation of a "pre-history" of Hegel's thought, in which Romanticism and anticlericalism combine with a passion for both Hellenism and philosophy. This moment takes place between the Systemfragment of Frankfurt (1800) and the Phenomenology (1807).

1.2.45. Hyppolite, Jean. "Les travaux de jeunesse de Hegel d'après des ouvrages récents." Revue de métaphysique et de morale 42 (1935): 399-426, 549-579.

Using principally works by Richard Kroner (Von Kant bis Hegel, Tübingen, 1921-1924), Nicolaï Hartmann (Die Philosophie des deutschen Idealismus, Berlin, 1923) and Jean Wahl (Le malheur de la conscience dans la philosophie de Hegel, Paris, 1929), Jean Hyppolite carefully delineates the evolution of Hegel's thought and distinguishes three main periods: Tübingen (1788-1793), Bern (1793-1796), Frankfurt am Main (1797-1800), and ends with the beginning of the Jena period in 1801, when Hegel meets 
Schelling.

1.2.46. Hyppolite, Jean. "Vie et prise de conscience de la vie dans la philosophie hégélienne d'Iéna." Revue de métaphysique et de morale 45 (1938): 45-61.

Focuses on the philosophy of the Jena period. Should be read in conjunction with Koyre (1.2.44) and Wahl's Malheur de la conscience. Reprinted in Etudes sur Marx et Hegel. Paris, 1955.

1.2.47. Hyppolite, Jean. "La signification de la révolution française dans la Phénoménologie de Hegel." Revue philosophique de la France et de L'Ćtranger (1939).

From the preface of Phenomenologyin which Hegel defines his time as one of transition, Hyppolite carefully studies the notions of liberty and state, and the relations between them before focusing on the preparation of the French Revolution in the Phenoménologie.

We should also mention the following works by Hyppolite published after 1940:

1.2.48. Hyppolite, Jean. "La conception hégélienne de l'état et sa critique par Karl Marx." Cahiers internationaux de sociologie 2 (1946): 142-161.

1.2.49. Hyppolite, Jean. "L'aliênation hégélienne et la critique" (1945). Atti del Congresso internazionale di filosofia promosso dall 'istituto di studi filosfici. Roma 15-20 novembre 1946. Milano: Castellani, 1947. 53-55.

1.2.50. Hyppolite, Jean. "L'existence dans la phénoménologie de Hegel." Etudes gérmaniques 2.2 (1946): 132-141. Also in Jean Hyppolite, Figures de la pensée philosophique, écrits de Jean Hyppolite (1931-1968). Paris: Presses Universitaires de France, 1971. 1:91-103.

1.2.51. Hyppolite, Jean. Genèse et structure de la phénoménologie de l'esprit de Hegel. Paris, 1946. Reviewed by Roger Caillois, Les Temps modernes (April, 1948): 1898-904. Transl. Genesis and 
Structure of Hegel's Phenomenologyof Spirit, Samuel Cherniak and John Heckman (Evanston: Northwestern UP, 1974).

1.2.52. Hyppolite, Jean. "Situation de l'homme dans la 'phénoménologie hégélienne'." Les temps modernes 2 (April 1947): 1276-1289. Rpt. in Jean Hyppolite, Figures de la pensée philosophique, écrits de Jean Hyppolite (1931-1968). Paris: Presses Universitaires de France, 1971. 1:104-121.

1.2.53. Hyppolite, Jean. Introduction a la philosophie de l'histoire de Hegel. Paris: Seuil, 1948.

1.2.54. Hyppolite, Jean. "Humanisme et hegelianisme" (1949). Umanesimo e scienza politica: Atti del congresso internazionale di studi umanisti. (Milan, 1951): 217-228.

1.2.55. Hyppolite, Jean. "Aliénation et objectivation: à propos du livre de Lukács sur 'La jeunesse de Hegel'." Etudes germaniques nr. 22 (1951): 117-124; nr. 25 (1952): 37-43. Rpt. in Jean Hyppolite, Figures de la pensée philosophique, écrits de Jean Hyppolite (1931-1968). Paris: Presses Universitaires de France, 1971. 1:122-145.

1.2.56. Hyppolite, Jean. "Essai sur la Logique de Hegel." Revue internationale de philosophie 19 (1952): 35-49.

The articles $(1.2 .46,47,48,49,52,55,56)$ were reprinted as chapters in Etudes sur Marx et Hegel (Paris, 1955), a work that Hyppolite himself considered to be a sequel to his Introduction a la Philosophie de l'Histoire de Hegel (Paris: Rivière 1948).

Hyppolite not only stabilized Hegelian studies, but with his two main books--Genèse et Structure de la phénomenologie (1.2.38) and Introductiona la philosophie de l'histoire (1.2.53)--he "indigenizes" Hegel, as Michel Foucault might have put it. The first book is both a guide to a reading of the Phenomenology and an interpretation. In the Introduction, Hyppolite introduces the reader to Hegel's conception of history in a dynamic way: the works of the young Hegel are used as well as those of the mature. They conflict and complement each other a propos of the tension existing between the "spirit of the Ancient City" and the spirit of Christianity. The philosophy of history presented is one in which the 
incarnation of the infinite opposes that of the finite, that of the universal opposes that of the particular.

Hegelian par excellence and scrupulously exemplary in his "effort d'objectivite," to use Canguilhem's words (1948-49, XXVIII-XXIX: 293), Hyppolite would have subtly marked Hegel's fate in France, according to Michel Foucault. In effect,

\begin{abstract}
Hyppolite sought out and explored all the issues, as though his chief concern had become: can one still philosophize where Hegel is no longer possible? Can any philosophy continue to exist that is no longer Hegelian? Are the non-Hegelian elements in our thought necessarily non-philosophical? Is that which is anti-philosophical necessarily non-Hegelian? As well as giving us this Hegelian presence, he sought not merely a meticulous historical description: he wanted to turn Hegel into a schema for the experience of modernity (is it possible to think of the sciences, politics, and daily suffering as a Hegelian?) and he wanted, conversely, to make modernity the test of Hegelianism and, beyond that, of philosophy. For Hyppolite, the relationship with Hegel was the scene of an experiment, of a confrontation in which it was never certain that philosophy would come out on top. He never saw the Hegelian system as a reassuring universe: he saw in it the field in which philosophy took the ultimate risk. (L'Ordre du discours, Paris: 75-76.)
\end{abstract}

Hyppolite was not alone. One should note the important role of Alexandre Kojève who, from 1933 to 1939, taught Hegel, focusing on Phenomenologie, at the Ecole Pratique des Hautes Etudes. Among his publications, let us single out two:

1.2.57. Kojève, Alexandre. "Hegel, Marx et le christianisme." Critique, 3-4 (December, 1946): 339-366.

1.2.58. Kojève, Alexandre. Introduction à la lecture de Hegel. Ed. Raymond Queneau. Paris: Gallimard, 1947. 2nd rev. ed. 1962, rpt. 1968, 1971. Transl. in abridged form as Introduction to the Readings of Hegel, ed. Allan Bloom, transl. James H. Nichols, Jr. (New York: Basic Books, 1969).

An edited synthesis of Kojève's course at the Ecole Pratique, 1933-1939.

Other important contributions to Hegelian studies worth mentioning are: 
1.2.59. Lowith, K. La conciliation hégelienne. Paris, 1935.

1.2.60. Niel, Henri. De la médiation dans la philosophie de Hegel. Paris: Aubier, 1945. Reviewed by Jean Hyppolite in Dieu vivant 6 (1946).

1.2.61. Niel, Henri. "L'interprétation de Hegel." Critique 18 (November, 1947): 426-437.

1.2.62. Grégoire, Franz. Aux sources de la pensee de Marx: Hegel, Feuerbach. Louvain, 1947.

1.2.63. Grégoire, Franz. "L'état et la vie spirituelle de l'homme selon Hegel." Tijdschrift voor Philosophie 9.4 (1947): 637-660.

1.2.64. Grégoire, Franz. "Hegel et la divinité de l'état." Actes du IIF Congrès des Sociétés de philosophie. Louvain, 1947. 242-253.

1.2.65. Cornu, Auguste. "L'Idée d'aliénation chez Hegel, Feuerbach et Karl Marx." Pensée 17 March-April (1948): 63-75.

1.2.66. Dufrenne, Mikel. "Actualité de Hegel." Esprit 16 (September 1948): 396-408. Rpt. in Mikel Dufrenne, Jalons. The Hague: Nijhoff, 1966. 70-83.

1.2.67. Canguilhem, Georges. "Hegel en France." Revue d'histoire et de philosophie religieuses (1948-49): 282-297.

1.2.68. Lefebvre, Henri. "Marxisme et sociologie." Cahiers internationaux de sociologie 4.3 (1948): 48-74.

1.2.69. Bonnel, Pierre. "Hegel et Marx à la lumière de quelques travaux contemporains." Critique 34 (March 1949): 221-332.

1.2.70. Weil, Eric. Hegel et l'etat. Paris: Vrin, 1950. Reviewed by A. de Waelhens in Revue philosophiqe de Louvain 49 (1951): 471-473.

1.2.71. Weil, Eric. "Lukács: Der junge Hegel." Critique, nr. 41 (October, 1950): 91-93. 
In the preceding list, one should note the particular usefulness of Dufrenne's (1.2.66) and Canguilhem's (1.2.67) articles: they sum up in a critical manner the state of Hegelian studies in France from the 1930s to the 1950s.

Finally, the Hegelian "effect" can be observed in the first philosophies of Maurice Merleau-Ponty and Jean-Paul Sartre:

1.2.72. Sartre, Jean-Paul. L'être et le néant, essai d'ontologie Phénoménologique. Paris: Gallimard, 1943. Being and Nothingness: An Essay in Phenomenological Ontology. Transl. Hazel E. Barnes. New York: Philosophical Library, 1956.

1.2.73. Merleau-Ponty, Maurice. Phénoménologie de la perception. Paris: Gallimard, 1945. Transl. as Phenomenologyof Perception. Colin Smith. New York: Humanities/London: Routledge and Kegan Paul, 1962.

1.2.74. Merleau-Ponty, Maurice. "L'existentialisme chez Hégel." Les temps modernes 1.7 (April, 1946): 1311-1319. Rpt. in Maurice Merleau-Ponty, Sens et Non-Sens. Paris: Nagel, 1948. 125-139. Transl. in Maurice Merleau-Ponty, Sense and Non-Sense. Herbert L. Dreyfus and Patricia Allen Dreyfus. Evanston: Northwestern UP, 1964. 63-70.

\section{From the 19503}

From the 1950s on, Hegel's effect is so pervasive that one should take seriously Foucault's question as to whether it is possible to philosophize where Hegel is absent. The recent overview of Vincent Descombes aptly describes the situation of Hegel in contemporary French thought:

In the recent evolution of philosophy in France we can trace the passage from the generation known after 1945 as that of the three H's' to the generation known since 1960 as that of the three masters of suspicion': the three H's being Hegel, Husserl and Heidegger, the three masters of suspicion, Marx, Nietzsche and Freud. This is not to say that the Hegelians or the Husserlians vanished abruptly from the scene in 1960. But those who persisted in invoking the three H's, or any one of them, after that date, would have been the first to admit that their position was no longer dominant. In argument, they were thus obliged to take the common doxa into account and to defend 
themselves in advance against the objections likely to be raised in the name of the new trinity. Our object, then, will be to account for this change. (Descombes, Modem French Philosophy, Cambridge, 1980:

3).

Here are some very excellent titles that are indicative of a permanence of Hegelian problematics in French philosophy after 1950:

1.3.0. Asveld, Paul. Hegel reformateur religieux, 1793-1796. Louvain, 1952.

1.3.1. Hyppolite, Jean. "Ruse de la raison et histoire chez Hegel." Congresso internazionale di studi umanistici (Rome, 1952). Rpt. in Jean Hyppolite, Figures de la pensée philosophique, écrits de Jean Hyppolite (1931-1968). Paris: Presses Universitaires de France, 1971. 1:150-157.

1.3.2. Hyppolite, Jean. Logique et existence: essai sur la Logique de Hegel. Paris: Presses Universitaires de France, 1953.

1.3.3. Asveld, Paul. La pensée religieuse du jeune Hegel: Liberté et aliénation. Louvain, 1953.

1.3.4. Desanti, Jean. "Hegel, est-il le père de l'existentalisme?" La Nouvelle critique 6, nr. 56 (1954): 91-109.

1.3.5. Hyppolite, Jean. Etudes sur Marx et Hegel. Paris, 1955. Transl. as Studies on Marx and Hegel. Transl. John O'Neill (New York: Basic Books, 1969).

1.3.6. Bataille, Georges. "Hegel, I'homme et l'histoire." Monde Nouveau 11, nr. 96-97 (1956): 20-33, 1-14.

1.3.7. Hyppolite, Jean. "La phénoménologie de Hegel et la pensée française contemporaine." (1957). In Jean Hyppolite, Figures de la pensée philosophique, écrits de Jean Hyppolite (1931-1968). Paris: Presses Universitaires de France, 1971. 1:230-241.

1.3.8. Sartre, Jean-Paul. Critique de la raison dialectique. Vol. 1. Paris: Gallimard, 1960.

1.3.9. Merleau-Ponty, Maurice. "L'ontologie cartésienne et l'ontologie 
aujourd'hui; Philosophie et non-philosophie depuis Hegel (textes commentés)." [Cours au College de France, 1961]. Published as "Philosophie et non-philosophie depuis Hegel. I-II. Notes de cours." Ed. Claude Lefort. Textures 6, nrs. 8-9 (1974): 82-129, 7, nrs. 10-11 (1975): 145-173. Transl. as "Philosophy and NonPhilosophy since Hegel," by Hugh J. Silverman in Telos, nr. 29 (Fall, 1976): 43-105. Also in Philosophy and Non-Philosophy since Merleau-Ponty. Ed. Hugh J. Silverman. New York and London: Routledge, 1988. 9-83.

1.3.10. Garaudy, Roger. Dieu est mort: étude sur Hegel. Paris: Presses Universitaires de France, 1962.

1.3.11. Wahl, Jean. La logique de Hegel comme Phénoménologie. Paris: Centre de Documentation Universitaire, 1965.

1.3.12. Hyppolite, Jean. 'Commentaire parlé sur la 'Verneinung' de Freud." (1955). In Jacques Lacan, Ecrits. Paris Seuil, 1966.

1.3.13. D'Hondt, Jacques. Hegel philosophe de l'histoire vivante. Paris: Presses Universitaires de France, 1966.

1.3.14. Derrida, Jacques. L'écriture et la différence. Paris: Seuil, 1967. Transl. as Writing and Difference. Transl. Alan Bass. Chicago: U of Chicago Press; London: Routledge \& Kegan Paul, 1978.

1.3.15. Derrida, Jacques. De la grammatologie. Paris: Editions de Minuit, 1967. Transl. as Of Grammatology. Gayatri Chakravorty Spivak. Baltimore: Johns Hopkins UP, 1975.

1.3.16. Garaudy, Roger. La pensée de Hegel. Paris: Bordas, 1967.

1.3.17. D'Hondt, Jacques. Hegel, sa vie, son oeuvre, avec un exposé de sa philosophie. Paris: Presses Universitaires de France, 1967.

1.3.18. D'Hondt, Jacques. Hegel et son temps: Berlin 1818-1831. Paris: Editions sociales, 1968.

1.3.19. D'Hondt, Jacques. Hegel secret: recherches sur les sources cachées de la pensée de Hegel. Paris: Presses Universitaires de France, 1968. 
1.3.20. Labarrière, Pierre-Jean. Structures et mouvement dialectique dans la Phénoménologie de l'esprit de Hegel. Paris: AubierMontaigne, 1968.

1.3.21. Hyppolite, Jean. Figures de la pensée philosophique, Ecrits de Jean Hyppolite (1931-1968). Paris: Presses Universitaires de France, 1971.

1.3.22. Derrida, Jacques. Marges de la philosophie. Paris: Editions de Minuit, 1972. Transl. as Margins of Philosophy. Alan Bass. Chicago: U of Chicago Press; Hassocks: Harvester Press, 1982.

1.3.23. D'Hondt, Jacques. De Hegel a Marx. Paris: Presses Universitaires de France, 1972.

1.3.24. Derrida, Jacques. Glas. Paris: Editions Galilee, 1974. Transl. as Glas. John Leavey and Richard Rand. Lincoln: $U$ of Nebraska Press, 1986.

1.3.25. Ricoeur, Paul. "Hegel aujourd'hui." Etudes théologiques et religieuses 49.3 (1974): 335-355.

1.3.26. Derrida, Jacques. "Speech and Writing according to Hegel." Man and World 11 (1978): 107-130.

1.3.27. Labarrière, Pierre-Jean. "La Phénoménologie de l'esprit" de Hegel. Introduction à une lecture. Paris: Aubier-Montaigne, 1979.

\section{SECONDARY LITERATURE}

The secondary literature on Hegel in France--bibliographies, commentaries, introductions, overviews, monographs on particular problems, etc.,--is immense. In this part, we present alphabetically some titles which are both indicative of the variety of issues and some orientations in French philosophy which (directly or indirectly, explicitly or implicitly) claim to be related to, and at any rate refer to Hegel or, at least, to his legacy. Some of the books included--e.g. those of Mark Poster, Michel Contat and Michel Rybalka, the Lapointes or Frans Vansina, etc. concern Hegel through a French intermediary. They are useful in so far as they clearly mark what is today the integration of Hegel's insights into a 
French horizon.

Indeed, a student specializing in this field should move quickly beyond this introductory and highly limited bibliography. This selected bibliography constitutes a first step toward an exhaustive list of works. It is divided in two parts: (1) bibliographies and overviews; (2) specific moments.

\section{Bibliographies and Overviews}

2.1.1. Alexander, Ian W. "The Phenomenological Philosophy in France: An Analysis of its Themes, Significance and Implications." In Currents of Thought in French Literature: Essays in Memory of G. T. Clapton. Oxford: Basil Blackwell, 1965. 325-351.

2.1.2. Asveld, Paul. "Zum Referat von Walter Biemel über die Phănomenologie des Geistes und die Hegelrenaissance in Frankreich." Hegel-Studien, Beiheft 11, Stuttgarter HegelTagung 1970. Ed. Hans-Georg Gadamer. Bonn: Bouvier, 1974. 657-664.

2.1.3. Basch, Victor. "De la philosophie politique de Hegel: à propos d'un livre récent." Revue philosophiquede la France 56 (1931): 381-408.

2.1.4. Baugh, Bruce. "Subjectivity and the Begriff in Modern French Philosophy." The Owl of Minerva 23.1 (1991): 63-76.

2.1.5. Biemel, Walter. "Die Phănomenologie des Geistes und die Hegel-Renaissance in Frankreich." Hegel-Sudien, Beiheft 11, Stuttgarter Hegel-Tagung 1970. Ed. Hans-Georg Gadamer. Bonn: Bouvier, 1974. 643-655.

2.1.6. Butler, Judith. "Geist ist Zeit: French Interpretations of Hegel's Absolute." Berkshire Review 21 (1985): 66-80.

2.1.7. Butler, Judith. Subjects of Desire: Hegelian Reflections in Twentieth-CenturyFrance. New York: Columbia UP, 1988.

2.1.8. Descombes, Vincent. Le même et l'autre. Quarante-cinqans de 
philosophie française (1933-1978). Paris: Editions de Minuit, 1979. Transl. as Modern French Philosophy, L. Scott-Fox and J.M. Harding (Cambridge and New York: Cambridge University Press, 1979).

2.1.9. D'Hondt, Jacques. "Les études hegéliennes." Doctrines et concepts 1937-1987. Retrospective et prospective: cinquante ans de L'Association des Sociétés de Philosophie de Langue Française. Ed. Andre Robinet. Paris, 1988. 153-164.

2.1.10. Eckles, L.E. La fortune intellectuelle de Hegel en France au 19 siècle. Paris, 1952. [dissertation]

2.1.11. Fetscher, Iring. "Hegel in Frankreich." Antares: Französische Hefte für Kunst, Literatur und Wissenschaft 3 (1953): 3-15.

2.1.12. Heckman, John. "Hyppolite and the Hegel Revival in France." Telos 16 (Summer, 1973): 128-145. Also published as the "Introduction" in Jean Hyppolite, Genesis and Structure of Hegel's Phenomenologyof Spirit. Transl. Samuel Cherniak and John Heckman. Evanston: Northwestern University Press, 1974. xv-xli.

2.1.13. Kline, George L. "The Existentialist Rediscovery of Hegel and Marx." Sartre: A Collection of Critical Essays. Ed. M. Warnock. Garden City, NY, 1971): 284-

2.1.14. Koyré, Alexandre. "Rapport sur l'état des études hégéliennes en France." Verhandlungen des Ersten Hegel-Congresses, vom 22. bis 25. April $1930 \mathrm{im} \mathrm{Haag.} \mathrm{Ed.} \mathrm{B.} \mathrm{Wigersma.} \mathrm{Tubingen:} \mathrm{J.C.B.}$ Mohr/Haarlem: N/V H.D. Tjeenk Willink \& Zn, 1931. 80-105. Also in Revue d'histoire de la philosophie 5.2 (April-June 1931): 147-171. Rpt. with an update in Alexandre Koyre, Etudes d'histoire de la pensée philosophique. Paris: Armand Colin, 1961. 205-230. Also in Revue d'histoire de la philosophie 5.2 (April-June 1931).

2.1.15. Negri, A. "Gli Studi Hegeliana in Francia (1945-1965)." Cultura e scuola 5 (1966): 157-165.

2.1.16. Pitkethly, L.J. Hegel in modern France (1900-1950). London, 
1975. [dissertation]

2.1.17. Poster, Mark. "The Hegel Renaissance." Telos 16 (Summer, 1973): 109-127.

2.1.18. Poster, Mark. Existential Marxism in Postwar France: From Sartre to Althusser. Princeton: Princeton University Press, 1975.

2.1.19. Regnier, Marcel. "Hegel in France." The Bulletin of the Hegel Society of Great Britain 8 (1983): 10-21.

2.1.20. Roth, Michael S. Knowing and History: Appropriations of Hegel in Twentieth-CenturyFrance. Ithaca/London: Cornell UP, 1988.

2.1.21. Tortignon, Pierre. Les philosophes française d'aujourd'hui. Paris: Presses Universitaires de France, 1967.

2.1.22. Totok, Wilhelm, ed. Handbuch der Geschichte der Philosophie. V: Bibliographie 18. und 19. Jahrhundert. Frankfurt a. M.: Vittorio Klostermann, 1986. 216-302.

\section{Specific Moments}

2.2.1. Auffret, Dominique. Alexandre Kojève: La philosophie, l'état, la fin de l'histoire. Paris: Bernard Grasset, 1990.

2.2.2. Baptist, Gabriella and Hans-Christian Lucas. "Wem schlägt die Stunde in Derridas Glas? Zur Hegelrezeption und-kritik Jacques Derridas." Hegel-Studien 23 (1988): 139-179.

2.2.3. Biemel, Walter. "Das Wesen der Dialektik bei Hegel und Sartre." Tijdschrift voor filosofie 20 (1958): 269-300.

2.2.4. Clark, Timothy. "Hegel in Suspense. Derrida/Hegel and the question of prefaces." Philosophy Today 29 (1985): 122-134.

2.2.5. Contat, Michel and Michel Rybalka. Les écrits de Sartre. Chronologie, bibliographie commentée. Paris: Gallimard, 1970.

2.2.6. Contat, Michel, and Michel Rybalka. "Chronologie de Sartre." Magazine Litteraire 103-104 (September, 1975): 9-49. 
2.2.7. Cooper, Barry. "Hegelian Elements in Merleau-Ponty's La structure du comportement." International Philosophical Quarterly 15.4 (1975): 411-423.

2.2.8. D'Hondt, Jacques. "Première vue française sur Hegel et Schelling (1804)." Hegel-Studien, Beiheft 20, Hegel in Jena. Ed. Dieter Henrich and Klaus Düsing (Bonn: Bouvier, 1980): 45-57.

2.2.9. Doz, André. "Véra, traducteur et interprète de Hegel." Annali della Scuola Normale Superiore. Pisa 16 (1986): 1265-1277.

2.2.10. Fry, Christopher Martin. Sartre and Hegel: The Variations of an Enigma in "L'être et le néant". Bonn: Bouvier, 1988.

2.2.11. Gasche, Rodolphe. "Nontotalization without spuriousness: Hegel and Derrida on the Infinite." Journal of the British Society for Phenomenology(1986): 289-307.

2.2.12. Hammel, Eckhard. "Hegel und die Dingproduktion. Ein Einblick in Lacans Hegel-Rezeption." Hegel-Studien 23 (1988): 227-244.

2.2.13. Hartmann, Klaus. Grundzüge der Ontologie Sartres in ihrem Verhältnis zu Hegels Logik. Eine Untersuchung zu 'L'être et le néant'. Berlin: W. de Gruyter 1963. Transl. as Sartre's Ontology: A Study of 'Being and Nothingness' in the Light of Hegel's 'Logic'. Evanston: Northwestern University Press, 1966.

2.2.14. Haute, P. van. "Lacan en Kojève: het imaginaire en de dialectiek van de meester en de slaaf." Tijdschrift voor Philosophie 48 (1986): 391-415.

2.2.15. Kimmerle, Heinz. "Über Derridas Hegeldeutung." Philosophie und Poesie. ed. A. Gethmann-Siefert. Stuttgart-Bad Cannstatt: fromann-holzboog, 1988. 415-432.

2.2.16. Kruks, Sonia. "Merleau-Ponty, Hegel and the Dialectic." Journal of the British Society for Phenomenology 7.2 (1976): 96-110.

2.2.17. Lapointe, François and Claire C. Lapointe. Maurice MerleauPontyand His Critics: An International Bibliography(1942-1976) 
preceded by a Bibliography of Merleau-Ponty's Writings. New York/London: Garland, 1976.

2.2.18. Lucas, Hans-Christian. "Zwischen Antigone und Christiane: Die Rolle der Schwester in Hegels Biographie und Philosophie und in Derridas Glas." Hegel-Jahrbuch 1984-85 (1988): 409-442.

2.2.19. Metraux, Alexandre. "Bibliographie de Maurice Merleau-Ponty." In Xavier Tilliette, Merleau-Ponty ou la mesure de l'homme. Paris: Seghers, 1971. 173-183.

2.2.20. Redding, Paul. "Hermeneutic or Metaphysical Hegelianism? Kojève's Dilemma." The Owl of Minerva 22.2 (1991): 175-190.

2.2.21. Riley, Patrick. "Introduction to the Reading of Kojève." Political Theory9.1 (1981): 5-48.

2.2.22. Rosca, D.D. L'influence de Hegel sur Taine, théoricien de la connaisance et de l'art. Paris: J. Gamber, 1928.

2.2.23. Roth, M. S. "A Problem of Recognition: Alexander Kojève and the End of History." History and Theory 24.3 (1985): 293-306.

2.2.24. Silverman, Hugh J. "Heidegger and Merleau-Ponty: Interpreting Hegel." In Radical Phenomenology: Essays in Honor of Martin Heidegger. Ed. John Sallis. Atlantic Highlands, NJ: Humanities Press, 1978. 209-224.

2.2.25. Vansina, Frans. "Selected Bibliography of Ricoeur's English Works." Philosophy+ Social Criticism 14.2 (1988): 217-235.

2.2.26. Vansina, Frans. "Selected Bibliography of Ricoeur's English Works." Bulletin de la Société Américaine de Philosophie de Langue Française 3.3 (1991): 235-256.

2.2.27. Verstraeten, P. "L'homme du plaisir chez Hegel et l'homme du désir chez Lacan." Rev. Univ. Bruxelles nr. 3-4 (1976): 351-394.

2.2.28. Wahl, Jean. "Le rôle de A. Koyré dans le développment des études Hégéliennes en France." Hegel-Studien, Beiheft 3, HegelTage Royaumont 1964: Beiträge zur Deutung der 
Phänomenologie des Geistes 1966. Ed. Hans-Georg Gadamer. Bonn: Bouvier, 1966. 15-26.

2.2.29. Wilcocks, Robert. Sartre: A Bibliography of International Criticism. Edmonton: University of Alberta P, 1975.

DUKE UNIVERSITY

CARLETON UNIVERSITY
V. Y. Mudimbe

A. Bohm 